\author{
H.O. Sirenko ${ }^{1}$, M.I. Martynyuk ${ }^{1}$, V.P. Svidersky ${ }^{2}$
}

\title{
Problem of Selection of Lubricants for ethelene High-Pressure Compressors. 1. Statement of a question of Selection of Lubricants for ethelene High-Pressure Compressors.
}

\author{
${ }^{I}$ Vasyl Stefanyk Precarpathian National University, 57, Shevchenko Str., Ivano-Frankivsk, 76018, Ukraine, \\ mar.martinyuk2904@gmail.com \\ ${ }^{2}$ Khmelnytsky National University, 11, Instytutska Str., Khmelnytsky, 29016, Ukraine
}

\begin{abstract}
Technology of obtaining and properties of ethylene compositions with different content of oils inside is researched. It is shown viscous-mechanical properties of polyethylene during addition of different quantity of lubricants. The results of researches of physics-mechanics and dielectric properties of polyethylene, synthesized during ingress of naphtene, with addition of $0,15 \%$ of different oils and thermooxidants.

Key words: polyethylene, oils, composition, polyglycol, dielectrical properties, thermooxidants, compressors.
\end{abstract}

Стаття поступила до редакиії 28.08.2018; прийнята до друку 15.09.2018.

\section{Introduction}

Maty investigations are known that apply to the question of solving the problem of lubricants selection for ethylene high-pressure compressors [1-8].

About $60 \%$ of high-pressure polyethylene is used for making products by the method of moulding and pressurizaticn-containers for food industry, products of domestic chemistry and childrens toys, $20 \%$ - for making special films, which are stable to thermo and photooxidation, films of capacitors and cable isolation with the heightened demands to the thermal aging and dielectric properties.

One of the most important problems of the making is selection the high quality oil for lubrication gaskets of cylinders or shafts of ethylene compressor. Delivering of fluid lubricant to the friction pair is realized either by injection it into the gas (phase of the suction- when using gaskets with the pistons rings) or by feeding it through the openings of gaskets element drilling (when glad gaskets are used) [2-9].

According to [9], in compressors at the compression up to $22-40 \mathrm{MPa}$ specific loadings of the gasket's elements reaches 7-10 MPa. In ethylene compressors gas compresses from 25 up to $110-120 \mathrm{MPa}$ on the first degree and from $110-120 \mathrm{MPa}$ up to $180-250$ (and even to 350) $\mathrm{MPa}$ on the second degree. Therefore, gasket elements of compressors experience during lubrication influence of the limit specific loadings from the hydrodynamic to limit regime and even to seizure. In ethylene compressors friction pair are used:

- the plunger made from the nitride steel 38 XMKDA or with coating of Wolfram carbide ; gasket elements made from the bronze Bp OCH 7-13-1;

- the bush of the cylinder made from the carbide of Wolfram (type BK-6), gasket rings made from the special alloyed cast iron or made from the bronze Bp OO 10-1.

The demands to wear resistance of surfaces are: intensity of wearing counterface from alloy BK-6 is ought to be not higher than $0.02 \mathrm{rnkm} /$ hour or $0.05 \mathrm{~mm}$ for 2500 hours of compressors work.

Pressure of pumping is $200-300 \mathrm{MPa}$, temperature of gas at the end of process reaches $373 \mathrm{~K}$, average velocity of piston - up to $2.5 \mathrm{~m} / \mathrm{s}$. Consumption of the oil for $1 \mathrm{t}$ final product - polyethylene for different compressors is from $0.7-0.9$ to $4.7-6.5 \mathrm{~kg}$.

Properties and nature of oils determine quality indicators of polyethylene and reliability of work of seal pistons and plungers of ethylene compressors. For lubrication of friction pair of these compressors mineral (naphthene - «white» oils), polybutene and polyglycol oils are used $[2,3]$.

\section{Materials}

Specifications to oils are: transparence, 
Table 1

Characteristic of properties of naphtene and polyglicol oils (information of producers)

\begin{tabular}{|c|c|c|c|c|c|}
\hline Index & Rieslla-33 & NKM-40 & NKM-70 & $\begin{array}{c}\text { Laprol 2502-2- } \\
70\end{array}$ & Orites-270 DS \\
\hline $\begin{array}{c}\text { Density,kg/m } \\
\text { at 293 K } \\
\text { at 303 K }\end{array}$ & 884 & 873 & 884 & & 1080 \\
\hline $\begin{array}{c}\text { Coefficient of } \\
\text { refraction of light (293 } \\
\text { K) }\end{array}$ & 1,4820 & 1,4794 & 1,4800 & - & - \\
\hline $\begin{array}{c}\text { Viscosity kinematic, } \\
\text { cs }\end{array}$ & & & & & \\
$\begin{array}{c}\text { at 293 K } \\
\text { at 303 K } \\
\text { at 373 K }\end{array}$ & 42,4 & 80,2 & 180 & 417 & 462 \\
\hline $\begin{array}{c}\text { Acid number, mg } \\
\text { KOH/g }\end{array}$ & 0,007 & 0,006 & 0,006 & 0,019 & 186 \\
\hline $\begin{array}{c}\text { Temperature of } \\
\text { solidification, K }\end{array}$ & 255 & 255 & 260 & - & 0,016 \\
\hline $\begin{array}{c}\text { Temperature, K } \\
\text { in closer crucible } \\
\text { in open crucible }\end{array}$ & 475 & 470 & 478 & 54 \\
\hline Content of water, \% & 0 & 488 & 498 & 489 & 493 \\
\hline $\begin{array}{c}\text { Content of mechanic } \\
\text { impurities, \% }\end{array}$ & 0 & 0 & 0 & 523 & 523 \\
\hline
\end{tabular}

colourlessness, absence of sediment and mechanic impurities, viscosity (not less than) $\sim 450 \mathrm{cs}$ at $293 \mathrm{~K}$, $200 \mathrm{cs}$ at $323 \mathrm{~K}, 50 \mathrm{cs}$ at $373 \mathrm{~K}$; flash temperature must be higher than $293 \mathrm{~K}$ from the maximal allowable (373 $383 \mathrm{~K}$ ), but better not lower than $473 \mathrm{~K}$; temperature of solidification - not higher than $273 \mathrm{~K}$; acid number -not more than $0.4 \mathrm{mg} \mathrm{KOH} / \mathrm{g}$; alkali number $0 \mathrm{mg} \mathrm{KOH} / \mathrm{g}$; content of moisture not more than $0.1 \%$; ashes $-0 \%$; point of turbidity of $1 \%$ solution -not more than $353 \mathrm{~K}$ [15-19].

According to manufacturers naphtene and polyglycol oils for the most quantity indicators satisfy these requirements. (Tabl. 1) [16-19].

Physic-and-chetnical properties and quantity of oil which ingresses in polyethylene determine its properties and use for cable isolation, products, which contact with food etc [16-19].

\section{Methods of testing}

Content of oil appreciably has an influence on such quality indicators as resistance to thermal aging and cracking and photooxidation processes, tangent of angle of dielectrical loss, dielectrical penetrability, breakdown electrical stress, sanitarian-hygienical properties. Content of oil in polyethylene is estimated by IR-spectroscopy (graduated by solution in $\mathrm{CC}_{4}$ ), tangent of angle of dielectric loss (frequency $10^{3}, 10^{4}, 10^{6}$ hertz), dielectric penetrability (frequency $10^{6}$ hertz). And also indexes of flow of plastics ( $\mathrm{g}$ in $10 \mathrm{~min}$.), changes of bound of strength and flow during tension, relative extension during breakage are found [10-15].

STATE STANDARD 16337-77 (for polyethylene) and STATE STANDARD 16336-77 (for compositions of polyethylene) determine demands to physic-and- chemical properties of polyethylene. Dielectrical properties of polyethylene and its composition are determined by:

- tangent of angle of dielectrical loss- STATE STANDARD 22372-77;

- electrical strength at variable voltage (frequency 50 hertz) - TATESTANDARD 64333-71;

- dielectrical penetrability (frequency $10^{5}$ hertz) STATE STANDARD 22372-71;

- resistance to thermal aging - STATE STANDARD 16336-77.

Block-effect (sticking of films together) and content of extraction substances which an; in initial polyethylene and which educe from it during secondary processing relate to quality indicators of polyethylene too. Content of these substances is estimated by excess of organic substance during lubrication of ethylene compressors with mineral oil and by using light mineral oils as solvents during peroxidative initiation of polymerization of ethylene.

Feasibility study of supplying of lubrication of seal elements relates not only to quality of polyethylene but to time wasted of compressor's equipment for repair (up to 2 - 7 days a year), which for high productivity producers (synthesis of polyethylene) turns as substantial economical losses. More over it is necessary to add that after every seal replacement necessity (100 - 300 hours) of feeding through lubricators excess of oil (for runningin of friction pair) comes into existence. Polyethylene made in this period contents of substantial quantity of oil that is not up to the requirements (for cable isolation) [10-19]. 


\section{Results and discussion}

Aim of work: consists in scientific search of lubricants for lubrication seal elements of ethylenes highpressure compressors, which are compatible with polyethylene. Tasks:

1. Studying of viscous-and-thermal properties of naphtene and polyglycol oils and selecting characteristics that the most complete characterize these properties.

2. Studying of antifriction properties of naphtene and polyglycol oils and finding indices, which the most complete characterize, these properties.

3. Studying of oils compatibility with polyethylene on the grounds of changes of physicmechanical, rheological and dielectric properties of composition [4-7].

\section{Solubility of fuel oil in ethylene}

Initial gas during production of polyethylene is dry polyethylene $(99.0-99,9 \%)$, the rest- impurities (propylene, ethane, methane, hydrogen, nitrogen and others non-aggressive gases). Content of $\mathrm{O}_{-}$is strictly controlled; even signs of it provoke polymerization of ethylene before reactor.

When finding the solution of lubricating of ethylene compressors it is important to take to account that temperature raising of gas leads to increasing of oils solubility in ethylene, but minimum of solubility displaces in side of higher pressure [10-12]. By mounting to high lubricating ability it is possible to bring down temperature in contact zone where maximum solubility of oil in ethylene is seen.

Besides that, according to $[2 ; 10 ; 12 ; 13]$ in general case increasing of molecular mass of oils leads to increasing of pressure intervaf where minimum of solubility is seen. Increasing of the molecular mass for the one homological row of hydrocarbons leads to decreasing of its solubility in ethylene. Hence, it is necessary to aspire to use oils with enough large molecular mass and viscosity.

It is known that isomers have better solubility in gases than substances with normal structure and mutual solubility of fuels and gases increases with approaching of theirs physic and chemical properties. Thus oils with ethylene or others hydrocarbon chains have better solubility in ethylene.

Maximum solubility of oil in ethylene (at temperature up to $323-373 \mathrm{~K}$ and pressure up to 200 $300 \mathrm{MPa}$ ) is sufficiently substantial and is, depending on nature of oil, from 300 to $3000 \mathrm{~g} / \mathrm{mm}^{3}$ of ethylene (recalculation on normal physic conditions), which is from 0.25 to $2.5 \mathrm{~kg}$ on 11 of compressed ethylene [10; $12 ; 14]$.

Increased mutual solubility of gas and oil (vaseline, naphtene, polybutene) will decrease operational properties of oils and lead to little term of capacity for work of seals.

Proceed from this information for lubricating of ethylene compressors it is necessary to use oils with big molecular mass and normal structure only then effect of raising antifriction properties because of increasing of viscosity will be reached.

Limitation of lubricating and expenditure of oils

One of ways of finding solutions of economy of fuel- lubricating substances and lowering quantity of oil which ingresses in ethylene is limitation of expenditure of oil during friction and wear of adjoining surfaces. Industrial experiment on finding optimum expenditure of oils Orites-270 DS, Risella-33 and Laprol-2502 was realized on ethylene compressors of plants of firms ICI with autoclave and «Polymir» with tubular reactor $[1 ; 2]$. These plants were differing by construction and productivity of ethylene compressors: productivity of plant «Polymir» four times higher than productivity of ICI plant.

Change of oil Risella-33 to polyglycol oil Laprol2502 and lowering its supply from 4.8 to $0.8 \mathrm{~kg} /$ hour on II cascade compressors (plant of ICI firm) lead to decreasing (two time) of term of capacity for work of seal elements from bronze, content of oil in polyethylene was about $0.05 \%$ and polyethylene by resistance to thermal aging, influence of oxygen, sanitarianhygienical, dielectrical and antiblocking properties was close to STATE STANDARD 16337-77. In that case when content of polyglycol oil Orites-270 DS in polyethylene was $0.02-0.04 \%$ commodity polyethylene was up to the requirements of STATE STANDARD and world standards [1].

When feeding of polyglzcol oils Orites-270 DS and Laprol-2502 on compressors of II cascade (plant «Polimir») was lowered from 41.5 to $14 \mathrm{~kg} / \mathrm{hour}$ accordingly content of oil in polyethylene increased three-four times and was $0.09-0.15 \%$ and $0.06-$ $0.08 \%$ accordingly for Orites-27- DS and $0.10-0.12 \%$ for oil Laprol-2502 к but this did not solve problem of obtain polyethylene for cable isolation (content of polyglicol oils in polyethylem; up to $0.02-0.04 \%$ ). Productivity of plant increased by 2.6 times and term of capacity for work of seal element form bronze decreased by piston rings of I degree compressors (before experiment 6 months) and 6-8 months by stuffing-box seals of II degree compressors (before experiment 12 months) [1-6].

Thus use of naphtene oils leads to lowering of coefficient of ethylene compressors and use of polyglicol oil - quality indexes of polyethylene.

Trends in finding solution of lubricating of ethylene compressors are:

- decreasing of quantity of polyglicol oil which ingresses into polyethylene;

- increasing of viscosity and loading ability and improvement of viscous-and-thermal characteristics of naphtene and polyglicol oils;

- replacement of seal elements riiade from bronze on high-quality durable polymeric materials (type of graphelon) [1.5-18].

In spite of constructive works on lowering of contaminations of oils in ethylene and accordingly lowering its content in polyethylene, work on creation of new synthetic lubricants and lubricating compositions which could provide increasing of reliability and term of service of seals of II cascade compressors and which do not have negative influence on properties of polyethylene, especially for cable isolation is still actual.

Proceeded from this information, for lubrication of ethylene compressors is necessary to use oils with big molecular mass and normal structure, only then effect of raising of antifriction properties because of viscosity 
increasing could be reached.

Using of oils in industries

In industry producers use naphtene oils which are made practically by one technology and which have similar physic-mechanic properties and which are different by trademark of firms-producers: Risella-33 (Shell, ELF Aquitaine- France), Vitorex-334, EssoChristo, 5350 (Mitsui, Japan), KPL-201 (British. Petroleum, Great Britain, Austrian branch- Technol, and Holland branch), NKM-40 (NPZ, Russia) etc (Tabl. 2). To synthetic oils show preference all key compressors firms: «Burckadt» (Switzeland), «Esslingen» (Germany), «Hitachi» (Japan), «Dresser-Clark» (USA), «NuovoPignone» (Italy), «Ingersoll-Rand», «Technocompressormash» of concern «Ukrrosmets 1» (Ukraine), fabrics named after Frunse (Ukraie) and «Borets» (Russia) etc [5-6].

However, naphtene oils when ingressing into polyethylene do not lower quality indexes of polyethylene have shortcomings:

- substantial solubility of ethylene in oil and as a result substantial lowering of viscosity and others hydrodynamic properties force to feed for lubrication substantial quantity of oil;

- substantial solubility of oil in ethylene which leads to substantial ingress of oil into ethylene and as a result increasing of extracting substances and "smoking" of mass during processing of polyethylene into products and to scale formation on piston's surfaces;

- low loading ability which force to limit of ethylene plants little and medium productivity (term of seal service 1000-4000 hours).

With the object of viscosity increasing naphtene oils have lowmoleeular polyisobutylene and polybutene Polyvis (firm Cosden Petroleum Co.) with the molecular mass from 400 to 1500 [15-19]. Producers use as well highmolecular polyisobutylene [1;2], methyl ether of methacrylic or acrylic acids [14], polyvynilbutyl ether [15]. Polyisobutylenes are more stable and do not polymerize under action of heat and pressure. Here wide diapason of viscosity change opens.

For increase of viscosity into naphtene oils ShellaOnclina-33 and Vitorex-334 0,7-0,8 \% wax O-Vax is given.

However, feeding into mineral oils thickens in big quantity as a rule changes course of curve of viscosity dependence from pressure, which acquires more steep character at low temperatures. This can lead to corking of feeding lines of lubricants to cylinder seals and deteriorate lubricating conditions of friction surfaces. For removal this effects in practice use additional heating of oil in tanks and feeding lines of lubricators, and some times high-pressure pipes.

For lubricating of ethylene compressors producers

Table 2

Trademarks and producgrs of oils for ethylene compressors

\begin{tabular}{|c|c|c|c|}
\hline Type & Trademark & Firm & Country \\
\hline Mineral & & France \\
& Risella-33 (Shell-Ondina33) & ELF Aquitaine & Japan \\
& Risella-17 & Mitsui & Japan \\
& Vitprex-334 & Mitsui & Japan \\
& Esso-Christo 5350 & Mitsui & Great Britain \\
(austr. branch)
\end{tabular}


Continuation of Table 2

Trademarks and producgrs of oils for ethylene compressors

\begin{tabular}{|c|c|c|c|}
\hline Type & Trademark & Firm & Country \\
\hline Polyglycol & $\begin{array}{c}\text { Orites-125 DS } \\
\text { Orites- 88 DS } \\
\text { Orites-270 DS } \\
\text { Orites-210 DS } \\
\text { Laprol 202 } \\
\text { Laprol 602 } \\
\text { Laprol 1002 } \\
\text { Laprol 2002 } \\
\text { Laprol 3002 } \\
\text { Laprol 503 } \\
\text { Laprol3003 } \\
\text { Laprol 3503-B 6 } \\
\text { Laprol 5003-2-B } 10 \\
\text { Laprol 5003-2-B12 } \\
\text { Laprol 6500-2-B } 18 \\
\text { Laprol 1601-4/2-50 } \\
\text { Laprol 1502-2-70 } \\
\text { Laprol 2502-2-70 } \\
\text { Laprol 4002-2-70 } \\
\text { Laprol 10002-2-70 } \\
\text { Laprol 3503-2-70 } \\
\text { Laprol 10003-2-70 } \\
\text { Syntheso-D 201 } \\
\text { Syntheso-D 202 } \\
\text { Ucon 75 H 1400 } \\
\text { Ucon 50 HB 660 } \\
\text { Poly-a-olephine } \\
\text { EHD-62/152H } \\
\text { Polyol LG 56 }\end{array}$ & $\begin{array}{c}\text { ELF Aquitaine } \\
\text { ELF Aquitaine } \\
\text { ELF Aquitaine } \\
\text { «Dolymersyntes» } \\
\text { (Volodymyr) } \\
\text { (Volodymyr) } \\
\text { (Volodymyr) } \\
\text { (Volodymyr) } \\
\text { (Volodymyr) } \\
\text { (Volodymyr) } \\
\text { (Volodymyr) } \\
\text { «Polymersynte» } \\
\text { (Volodymyr) } \\
\text { (Volodymyr) } \\
\text { (Volodymyr) } \\
\text { Kliiber } \\
\text { Kliiber } \\
\text { Union Carbide } \\
\text { IPChl Baku } \\
\text { Mobil-oil } \\
\text { Union Carbide } \\
\text { Mobil-oil } \\
\text { Mobil-oil } \\
\text { Mobil-oil } \\
\text { Mobil-oil } \\
\text { Mobil-oil } \\
\text { Mobil-oil } \\
\text { Mobil-oil } \\
\text { Mobil-oil }\end{array}$ & $\begin{array}{c}\text { France } \\
\text { France } \\
\text { France } \\
\text { Russia } \\
\text { Russia } \\
\text { Russia } \\
\text { Russia } \\
\text { Russia } \\
\text { Russia } \\
\text { Russia } \\
\text { Russia } \\
\text { Russia } \\
\text { Russia } \\
\text { Russia } \\
\text { Russia } \\
\text { Duetschland } \\
\text { Duetschland } \\
\text { USA (austr. brc.nch) } \\
\text { Azerbaijan } \\
\text { USA } \\
\text { USA } \\
\text { USA } \\
\text { USA } \\
\text { USA } \\
\text { USA } \\
\text { USA } \\
\text { USA } \\
\text { USA } \\
\text { USA }\end{array}$ \\
\hline Polyglycol with additives & $\begin{array}{c}\text { Breox CL } 660 \\
\text { BreoxCL } 1300 \\
\text { BreoxCL } 1314 \\
\text { BreoxCL } 1400 \\
\text { Breox PC } 13150 \\
\text { Breox PC } 1316 \\
\text { SynthesoD201 N } \\
\text { Ucon PE-150 } \\
\text { Ucon PE-350 } \\
\text { Poly-oolephine, } \\
\text { thickened } \\
\text { with } 4 \text { \% of polymer } \\
\text { SKEP }\end{array}$ & $\begin{array}{c}\text { British Petroleum } \\
\text { British Petroleum } \\
\text { British Petroleum } \\
\text { British Petroleum } \\
\text { Kliiber } \\
\text { Union Carbide } \\
\text { Union Carbide } \\
\text { IPChl Baku } \\
\text { IPChl Baku }\end{array}$ & $\begin{array}{c}\text { Great Britain } \\
\text { Great Britain } \\
\text { Great Britain } \\
\text { Great Britain } \\
\text { Deutschland USA } \\
\text { (austr. branch) } \\
\text { Azerbaijan }\end{array}$ \\
\hline
\end{tabular}

use as well pure polybutene oils Oritex L 100 (firm ELF Aquitaine), polybutene oil (firm Witco and Houfix 200), white oil BP Olex WM2631, thicken by complex additive: for increase of viscosity-polyisobutylene, inhibitor of oxidation $-0.1 \%$ solution of phenol compound, for increasing of antiwear properties $-0.1 \%$ ether compound.

Firm Burkhadt for high productivity compressors uses pure polybutene oils Polybutene-8, Polybutene-12 (Chevron), Indopol L100 (Amoco-Fina firm) or their mixtures with naphtene oils (lubricant Sonne bom-1200Witco Chemical Sonnebom firm- analogue Orites L66) [2].

Firms Ingersoll-Rand (USA), Dresser-Clark (USA),
Burkhadt (Switzerland), Nuovo-Pignone (Italy), Esslingen (Deutschland), Hitachi (Japan) (when pressure of ethylene is up to $350 \mathrm{MPa}$ ) use thickening oils CL 1000 PH LA 3, CL 1200 PH LA 3, CL 1500 PH LA 3 (Witco firm, USA, Holland's branch).

At positive compatibility of naphtene, polybutene and thickening white oils with polyethylene theirs maximum limiting content in polyethylene $-0.1 \%$ normalizes.

Increasing of individual capacity of plants for synthesis of polyethylene lead to transition to synthetic :i oils. For large technological lines was required equipment, which guarantee high coefficient of using working times. One of the essential factors directed to 
Table 3

Antifriction properties of naphtene and polyglycol oils during investigation of pair samples (bronze, graphelom-20) counterface (metaiceramic material) during low loading

\begin{tabular}{|c|c|c|c|}
\hline \multirow{3}{*}{ Lubricant } & \multirow{3}{*}{ Sample } & \multicolumn{2}{|c|}{$\begin{array}{l}\text { Wear intensity of the sample } J \\
\qquad\left(0^{8}\right) \mathrm{mm}^{3} /(\mathrm{N} \cdot \mathrm{m})\end{array}$} \\
\hline & & \multicolumn{2}{|c|}{ counterface } \\
\hline & & BK-11 & BK-6 \\
\hline Risella-33 & Bronze (firm «Kranz») & 1,48 & 1,17 \\
\hline Laprol 2502-2-70 & Bronze (firm «Kranz») & 2,40 & 2,05 \\
\hline Laprol 2002 & Bronze (firm «Kranz») & 2,02 & 1,30 \\
\hline Risella-33 & Bronze Бр ОФ 10-1 & 0,33 & 0,53 \\
\hline Laprol 2502-2-70 & Bronze Бр ОФ 10-1 & 0,83 & 0,76 \\
\hline Laprol 2002 & Bronze Бр ОФ 10-1 & 0,76 & 0,70 \\
\hline Risella-33 & Bronze Бp OC 12-2 & 0,32 & 0,53 \\
\hline Laprol 2502-2-70 & Bronze Бp OC 12-2 & 0,47 & 0,68 \\
\hline Laprol 2002 & Bronze Бр OC 12-2 & 0,42 & 0,62 \\
\hline Risella-33 & Bronze Бр БНТ 2,5-1-68 & 0,21 & 0,32 \\
\hline Laprol 2502-2-70 & Bronze Бр БНТ 2,5-1-68 & 1,05 & 1,55 \\
\hline Laprol 2002 & Bronze Бр БНТ 2,5-1-68 & 1,23 & 1,26 \\
\hline Risella-33 & Graphelon-20 & 1,50 & 1,56 \\
\hline Laprol 2502-2-70 & Graphelon-20 & 1,24 & 1,17 \\
\hline Laprol 2002 & Graphelon-20 & 0,95 & 0,77 \\
\hline
\end{tabular}

this increasing was using synthetic lubricants with high antiwear and antiseizure properties.

These oils are:

- lowmoleeular Orites-88 (ELF, France);

- highmolecular Orites-27Q. DS (ELF, France) with ratio of ethylene and propylene oxides 72.8:27.2 (analogue of this oil Laprol 2502-2-70);

- BreoxCL 1300, BreoxCL 1400, BreoxCL 660 without additive and with additive Breox PC 1314, Breox PC 1315, Breox PC 1316 (British Petroleum Co.);

- Syntheso D 201, Syntheso D $201 \mathrm{~N}$ (with additive), Syntheso D 202 (Bochaco, Kliiber, Duetschland); lowviscous Ucon 75 H1400, Ucon PE-159 and highviscous Ucon PE-320, Ucon PE-350 (Union Carbide, USA);

- EXD 62/152H, EHD62/152 $\mathrm{H}$ with ratio of ethylene and propylene oxides 48:52 (Mobiol-Oil, USA);

- highviscous Polyol LG-56.

Polyglycol oils in comparing with naphtene have advantages:

- low solubility in ethylene and at saturation by ethylene viscosity, antiseizure and antiwear properties do not change;

- have high adhesion and adsorption properties to surfaces of metals, moisten theirs surfaces well, form on them durable bounding layers, which determines theirs high antiseizure and antiwear properties;

- change viscosity not much (when pressure increases); when pressure is high change viscosity not thus much that canal for feeding of oil in cylinders and pipes become corked;

- have high viscosity and declivity viscous-and thermal characteristic.

Moreover, according to firm Esslingen term of work of seal elements during lubrication with polyglycol oils 3-5 times bigger and increases from 1000-4000 hours for naphtene and polybutene oils to 5000-15000 for polyglycol oils, According to firm ELF expenditure for It of polyethylene during transition from lubricating with naphtene oils to lubricating with polyglycol Orites 270 DS decreased from 3-4 to.) ke/t.

At the same time from 0.02 to $0.15 \%$ of oil ingress into polyethylene, which decreases durability of polyethylene to thermal aging and photooxidation processes, sanitarian-hygienical indexes and electroisolation properties.

Investigation of antifriction properties of naphtene and polyglycol oils during little loading with lubrication of pair bronze-WK-6 (WK-11) and graphelon-20-WK-6 (WK-11) [11-19].

Wearing of bronze (firm «Rranz»), Beryllium bronze Bp BHT-2.5-1-68, Tina-Stannum bronze Bp OC 12.2, Tina-phosphorous bronze Bp OO-10-land composition material on the base of aromatic polyamide phenilon C$2+20 \%$ of graphite fiber from hydrocellulose (viscose) graphelon-20 was investigated on three-pin-disk friction machine.

Samples were made in shape of three fingers with diameter $6 \mathrm{~mm}$ and height $15 \mathrm{~mm}$ (last sphere $6.35 \mathrm{~mm}$ ). Counterfaces were made by method of pressing and annealing of metal-ceramic bronze (wolfram group BK-6 and BK-11) as inserts with $d_{e}=45.0 \mathrm{~mm}, d,=25.0 \mathrm{~mm}$ and thickness $15 \mathrm{~mm}$ (HB 8200-8400 MPa; $R a_{0}-0,04-$ $0.06 \mathrm{mkm})$. Normal loading on one specimen JV) $=$ $67 \mathrm{~N}$, velocity of sliding $1,3 \mathrm{~m} / \mathrm{s}$, time of investigation 4 hours (friction track 16,14 km), temperature $591 \pm 275 \mathrm{~K}$. Lubricant - polyglycols Laprol 2502-2-70, Laprol 2002 and naphtene oil Risella-33 [11-19].

Intensity of wearing was calculated by diameter of wear spot (wear capacity):

$$
J=\frac{V}{N, S_{m m^{3} N-m}}
$$

where $V$ - average volume of wear capacity on one sample $\left[\mathrm{mm}^{3}\right] ; \mathrm{N}$ - normal loading on one sample; S wear track [m].

Results of the wear intensity $J=(0.21$ - 
2.4) $-10^{\mathrm{s}} \mathrm{mm} / \mathrm{N}-\mathrm{m}$ (Tabl. 3) were calculated by diameters of wear spot $d_{w}=0.754-1.461 \mathrm{~mm}$ by which it is possible to estimate the limit of specific loading at the end of friction: $150-40 \mathrm{mPa}$.

As we can see from the Tabl.3, during little loadings $(\mathrm{TV}=67 \mathrm{~N})$ and relatively high sliding velocity $(\&=$ $1.3 \mathrm{~m} / \mathrm{s}$ ) for pair «bronze - BK-11» and «bronze - BK-6» preferences of polyglycol (statistic polymer of propylene and ethylene oxides Laprol-2502-2-70 and linear polypropyleneglycol Laprol 2002) oils to naphtene oil Risella-33 are not seen and on the contrary, for pair «graphelon-20-BK-H» and «graphelon-20-BK-6 polyglycols are more effective than naphtene oil.

Except samples of bronze (firm «Kranz») and $5 p$ ОФ 10-1, for which intensity of wearing in friction on BK-11 during lubrication with polyglycols $1.09-1.55$ time larger than on BK-6, for the rest of samples made frombronz.3 (Бp OC 12-2andBpBbIT 2,5-1 -68) wearing on BK-6 1.02-1.48 time bigger than on BK-11.

In general: wearing of samples made from bronze during lubrication with polyglycol oils 1.31-5.86 time during friction on $\mathrm{BK}-11$ and $1.11-4.84$ time during friction on BK-6 bigger than with naphtene oil.

For the future it is necessary to estimate the antiwear and antiseizure properties of oils by the results of investigations on the four-ball-friction machine [5-10] in the contact of working bodies of which the specific loadings $1350-7500 \mathrm{MPa}$ can be reached.

\section{Conclusions}

Analysis of results shows that for lubrication of ethylene compressors is necessary to use oils with big molecular mass and normal structure, only then effect of raising of antifriction properties because of viscosity increasing could be reached.

Were tested properties of antifriction properties of naphtene and polyglycol oils during little loading with lubrication of pair bronze-WK-6 (WK-11) and graphelon-20-WK-6 (WK-11)

In general: wearing of samples made from bronze during lubrication with polyglycol oils 1.31-5.86 time during friction on BK-11 and $1.11-4.84$ time during friction on BK-6 bigger than with naphtene oil

Sirenko H.O. - Professor, Doctor of Technical Sciences, Professor of Department of General and Applied Chemistry;

Martynyuk M.I. - Ph.D. student of Department of General and Applied Chemistry;

Svidersky V.P. - Ph.D (Tech.Sci.), Associate Professor of the Department of wear resistance and reliability of machines.

[1] A.M. Zavoyko, Y.Y. Novykov, H.A. Syrenko y dr., Khymycheskoe y neftyanoe mashynostroenye 1, 19 (1984).

[2] A.M. Zavoyko, Y.Y. Novykov , H.A. Syrenko, A.H. Platonov, NYYEЭKhYM 1, 3 (1987).

[3] H.A. Syrenko, R.V. Hrynevych, Y.Y. Novykov, Vsesoyuzn. nauch.-tekhn. konf. «Trybonyka y antyfryktsyonnoe materyalovedenye» (NPY, Novocherkassk, 1980).

[4] G.O. Syrenko. Nauk.zb. «Byuleten Vseukr. nauk, ta prof. tov-va im. M.Mixnovskogo» 9, 1 (1998).

[5] O. Gavryshov, A.M. Zavoyko, Visnyk Prykarp. un-tu im. Vasylya Stefanyka 3, 142 (2003).

[6] A.A. Tarzymanov, A.V. Maryashev, Trudy Kazanskoho khym.-tekhnoloh. yn-ta 90(73), 3 (1976).

[7] Y.R. Krychevskyy, Fazovne ravnovesyya v rastvorakh pry vysokykh davlennyakh (Hoskhymyzdat, Moskva, 1952).

[8] T.P. Zhuze Szhatye hazy kak rastvorytely (Nauka, Moskva, 1974).

[9] H.A. Syrenko, A.S. Smyrnov, Voprosy teoryy trenyya, yznosa y smazky 215, 38 (1969).

[10] R.A. Shahykhmetov, Yssledovanye vyazkosty, plotnosty masel y vlyyanye rastvorennoho haza na velychynu vyazkosty pry davlenyyakh do 100-200 MPa. Avtoref. kand. dys. (Kazan, 1981).

[11] L.V. Sukhareva, B.Yu. Kalynyn, A.V. Polyakov, Y.N. Andreeva, Plast. massy 3, 58 (1979).

[12] N.A. Korneeva, Plast. massy 3, 55 (1979).

[13] L.V. Sukhareva, B.Yu. Kalynyn, A.N. Karasev, Plast. massy 7, 56 (1979).

[14] H.A. Hladkovskyy, Plast, massy 8, 46 (1979).

[15] Y.Y. Novykov, M.Y. Frenkel', Y.S. Danylo, Plast. massy 8, 51 (1979).

[16] G.A. Syrenko, Tehnika 2, 179 (1985).

[17] N.A. Sirenko, O.V. Kuzyshyn, A.M. Zavoiko, Problems of tribology 4, 150 (2003).

[18] H.O. Sirenko, I.V. Sulyma, N.V.Shmaltser, Physics and Chemistry of Solid state 18(3), 365 (2017).

[19] H.O. Sirenko, M.I. Martynyuk, V.P. Svidersky, I.V. Sulyma and ect., Physics and Chemistry of Solid state 18(4), 460 (2017). 
Г.О. Сіренко ${ }^{1}$, М.І. Мартинюк ${ }^{1}$, В.П. Свідерський ${ }^{2}$

\section{Проблема вибору та властивостей мастильних матеріалів для етеленових компресорів надвисокого тиску. 1. Вимоги щодо властивостей мастильних матеріалів для етеленових компресорів надвисокого тиску}

${ }^{1}$ Прикарпатський національний університет імені Василя Стефаника, вул. Шевченка, 57, м. Івано-Франківськ, 76018, Україна, mar.martinyuk2904@ gmail.com

${ }^{2}$ Хмельницький національний університет, вул. Інститутська, 11, м. Хмельницький, 29016, Украйна

Досліджено технологію отримання та властивості етиленових композицій з різним вмістом мастил всередині. Показано в'язко-механічні властивості поліетилену при додаванні різної кількості мастильних матеріалів. Приведені результати досліджень фізико-механічних та діелектричних властивостей поліетилену, що синтезований при надходженні нафтенового масла, з додаванням 0,15\% різних мастил та термооксидантів.

Ключові слова: поліетилен, мастила, композиції, полігліколі, діелектричні властивості, термооксиданти, компресори. 